\title{
Hakan Kaya*
}

$\ddot{\mathbf{O z}}$

Yurtluk-ocaklık olarak idare edilen sancaklar "ocakzade" ifade edilen belli bir aile tarafından yönetilmiştir. Yurtluk-ocaklıkla yönetilen sancaklarda, aynı aileden olan kişiler yönetime getirilmekteydi. Ancak bazı araştırmacılar tam tersini iddia etmektedir. Bayezid sancakbeylerinin bazı dönemlerde sancak dışından atandığını dile getirmektedirler. Yapılan araştırmada Bayezid Sancağı'nı yöneten sancakbeylerin aynı aileden geldikleri ortaya konulmuştur. Özellikle Bayezid sancakbeyi İshak Paşa hakkında yanlış bilinen bazı bilgiler mevcuttur. Bu çerçevede İshak Paşa Sarayı'nın banisi olarak kabul edilen Bayezid sancakbeyi İshak Paşa ile Çıldır valisi Hasan Paşa'nın oğlu İshak Paşa'nın birbirine karıştırıldığı görülmektedir. Bu araştırmada İshak Paşa'nın kim olduğuna ve paşa hakkında yanlış bilinen bilgiler ayrıntılı bir şekilde ortaya konulacaktır.

Anahtar kelimeler: İshak Paşa, Bayezid, Çıldır, Sancak, Sınır, Ocakzade.

\section{AN INVESTIGATION OVER THE BAYEZID GOVERNOR OF ISHAK PASA}

\begin{abstract}
The sanjaks, which were managed as "yurtluk-ocaklik", had been directed by a certain family called "ocakzade". In the sanjak governed by the same family, were brought to the government. However, some researchers claimed the opposite. In some periods, sanjak rulers of Bayezid were appointed from the outside. In the study, it was revealed that the governors ruled the sanjak of Bayezid came from the same family. In particular, there is some wrong information about the governer of Bayezid, Ishak Pasha. In this context, it is seen that Ishak Pasha, who is considered as the constructor of Ishak Pasha Palace was interweaved with another Ishak Pasha, the son of the Governor of Çıldır Hasan Pasha. In this study, it is revealed that, there exists some wrong information on Ishak Pasha and this is presented in detail.
\end{abstract}

Keywords: Ishak Pasha, Bayezid, Cıldır, Sanjak, Border, Ocakzade.

\section{GíRiş}

Bayezid Sancağı, Osmanlı klasik sancak yönetimi dışında tımarın uygulandığı ve yurtluk-ocaklık olarak yönetildiği sancaklar arasında yer almaktadır. ${ }^{1}$ Osmanlı idari yapısında yurtluk-ocaklıkla yönetilen sancaklarda sancakbeyliği aynı aile içinde el

\footnotetext{
Article Types / Makale Türü: Research Article / Araştırma Makalesi

Received / Makale Geliş Tarihi: 12.02.2020 Accepted / Kabul Tarihi:25.03.2020

DOI: https://doi.org/10.26791/sarkiat.688521

*Ağrı İbrahim Çeçen Üniversitesi Fen-Edebiyat Fakültesi Tarih Bölümü, hkaya@agri.edu.tr.

ORCID ID: http://orcid.org/0000-0001-8904-965X

${ }^{1}$ Cumhurbaşkanlığı Arşiv Daire Başkanlığı Osmanlı Arşivi (BOA), Maliyeden Müdevver Defterleri (MAD. d) nr. 17679, 63-64.; Cumhurbaşkanlığı Arşiv Daire Başkanlığı Osmanlı Arşivi (BOA), Ruznamçe Defterleri (DFE. RZ. d.) nr. 167, 121-nr. 220-A, 84-85.
} 
değiştirerek devam etmekteydi. ${ }^{2}$ Osmanlı Kanunnamelerine göre yurtluk-ocaklık olarak idare edilen bölgeler şu şekilde ifade edilmektedir: "ve bunlardan birisi fevt olsa yahud edâ-yl hizmet eylemese, yurd ve ocă̆l olmağla, sancă̆l ve ocă̆l, evladına ve akrabasina verilir; hariçden kimesneye virilü-gelmemişdir."3

Ayn Ali Efendi ise Kavânin-i Al-i Osman Der-Hülâsa-i Mezâmin-i Defter-i Divân adlı eserinde yurtluk-ocaklıkla yönetilen sancakların idarecilerini aşağıdaki şekilde ifade etmektedir:

"Azl ve nasb kabul etmezler fevt olundukta oğullarina virülür harice virilmez lakin sancaklar gibi olup mahsulatı tahrir ve defter olunup içinde zeamet ve tımarı vardır sefer-i hümayun vaki oldukta zuama ve erbab-ı tımar ve alaybeyisi ile sancakbeyi olan sair sancaklar gibi beylerbeyisi ile kanun göçüp sefer hizmetin edâ iderler ferman olunan hizmete gelmez ise sancă̆ oğluna yahut akrabasına virilür."

Yukarıdaki kayıtta ifade edildiği üzere Osmanlı kanunnamelerinde yurtluk-ocaklıkla yönetilen yerlerin mahiyeti açıklanmıştır. ${ }^{5} \mathrm{Bu}$ çerçevede Bayezid sancakbeylerinin de aynı aileden gelen kişiler olduğu aşağıda ayrıntılı bir şekilde izah edilecektir. Ayrıca Bayezid sancakbeyi İshak Paşa'nın hangi nedenlerden dolayı Çıldır valisi İshak Paşa ile karıştırıldığı da kaynaklar çerçevesinde açıklanacaktır.

\section{18. Yüzyılda Bayezid Sancakbeyleri}

Bayezid sancakbeyliği yurtluk-ocaklık sistemiyle yönetildiğinden yönetim aynı aile içinde kalmaktaydı. Bu aileler genellikle bir aşirete mensubiyetleri olup, ailelerin sancak yönetiminde etkinlikleri olduğu bilinmektedir. Örneğin Bisyan aşireti 16. yüzyılın son çeyreğinde Diyarbakır'ın Meyafarkin (Silvan) Sancağı'ndan Bayezid Sancağı'na gelmiş ve aşiretin büyük bir kısmı Bayezid sancak dahilinde kalmıştır. Söz konusu aile/aşiret Bayezid sancakbeyliğinin yönetimini uzun bir süre kontrollerinde tutmuştur. ${ }^{6}$

Katip Çelebi 1635 Revan Seferi sonrası kaleme aldı̆̆ı eserinde bu noktada Bayezid Sancağı hakkında şu bilgileri vermektedir.

"Kal'a-i Bayezid Kotur şimalinde bir kal'a ve livâdır ve serhad-ı Acemdir. İki kal'a dahi buna tabidir. Biri, Diyadin kal'ası ve biri Hamur kal'ası. Bu livâyı Behlül Bey ocaklık tarikiyle zabt ider, bunlar dahi tevaif-i Ekraddan Besyan aşiretinden ğayet şeci ' taifelerdir. Kızllbaşlar bunlardan gayet havf iderlerdi.,"7

Bayezid sancakbeylerinin "ocakzade" olarak ifade edildiği görülmektedir. Arşiv belgelerine bakıldığında "ocakzade" ifadesinin yurtluk-ocaklıkla yönetilen

\footnotetext{
${ }^{2}$ Mehmet Öz, "Osmanlı İdaresinde Kürtler ve Özerklik: Efsane mi Gerçek mi? (XVI-XVIII. Yüzyıllar)", Türkiye Günlüğ̈̈ Dergisi 99 (Güz 2009): 154-169.

3 Ahmet Akgündüz, Osmanlı Kanunnameleri Hukuki Tahlilleri Merkezi ve Umumi Kanunnameleri 4. Kitap Kanuni Devri Kanunnameleri, (İstanbul: Fey Vakfi Yayınları, 1992), 476-477.

${ }^{4}$ Ayn Ali Efendi, Kavânin-i Al-i Osman Der-Hülâsa-i Mezâmin-i Defter-i Divân (Ankara: T.B.M.M Kütüphanesi Yazma Eserler, nr. KZ-334), 10-12.

5 Ayrıca taşra teşkilatı ve tevcih kayıtları hakkında ayrıntılı bilgi için bkz. Feridun M. Emecen-İlhan Şahin, “Osmanlı Taşra Teşkilatının Kaynaklarından 657-958 (1550-1551) Tarihli Sancak Tevcih Defteri, Belleten, 19/23, (1998).; Metin Kunt, Sancaktan Eyalete 1550-1650 Arasinda Osmanl Ümerasl ve Il İdaresi, İstanbul: Boğaziçi Üniversitesi Yayınları, 1978)

${ }^{6}$ Şeref Han Bitlisi, Şerefnâme, Çev. Abdullah Yegin, c. I, (İstanbul: Nûbihar Yayınları, 2013), 308. Ayrıntılı bilgi için bkz. Erdal Çiftçi, "Migration, Memory and Mythification: Relocation of Suleymani Tribes of the Northern Ottoman-İranian Frontier”, Middle Eastern Studies, 54/2, (2018): 270-288.

${ }^{7}$ Kâtip Çelebi, Kitab-ı Cihannüma li- Kâtip Çelebi, Tıpkıbasım, (Ankara: Türk Tarih Kurumu Yayınları, 2009), I: 326.; Hakan Kaya, Osmanl-Iran Sinırında Bir Serhad Sancăğ: Bayezid (1578-1648) (Doktora Tezi, Hacettepe Üniversitesi, 2018), 33.
} 
sancakbeylerinin ailesi (hanedan) için kullanılan bir terim olduğu anlaşılmaktadır. Örneğin 1122/1710 tarihli bir belgede Bayezid Sancağı'nın yurtluk-ocaklık olarak ocakzadelerden Ahmed Bey’e tevcih edildiği ifade edilmektedir. ${ }^{8}$ Başka bir arşiv belgesinde 'Eyalet-i Erzurum'da vaki Bayezid sancă̆l beyi yine ocakbeyzadelerinden aşair ve kabâil reaya ve beraya fukaralarının muhtarı olan Osman kullarına sadaka ve inâyet buyrulmuş iken" kaydı bulunmaktadır. ${ }^{9}$ Görüldüğü üzere sancağı yöneten aile üyeleri için ocakzade ifadesinin yanı sıra ocakbeyzade terimi de kullanılmıştır

İshak Paşa ile ilgili ihtilaflı olan meselenin daha iyi anlaşılması için 18. yüzyılda Bayezid sancakbeyliğini yapan şahısların yönetime geliş tarihlerine ve tarihi süreçte birbirleri arasındaki mücadeleye kısaca bakmakta fayda vardır. 18. yüzyılın başlarında İbrahim Paşa Bayezid sancakbeyliğinden azledilmiş ve onun yerine Mehmed Sani Bey getirilmiştir. İbrahim Paşa merkezi yönetim tarafından gönderilen emirlere uymadığ topladığı miri vergileri elinde tutarak devlete muhalefet ettiği iddia edilmiş ve yerine Mehmed Bey, muhtemelen Muhammed Pürbelali ${ }^{10}$, oğlu Mehmed Sani'nin getirilmesi uygun görülmüştür. ${ }^{11}$ Arşiv belgelerinden anlaşıldığına göre, Bayezid sancakbeyliği kısa bir süre sonra Mehmed Sani Bey'e tevcih edilmiştir. ${ }^{12} 1706$ 'da Bayezid'de yerel beyler arasında çıkan çatışmada Mehmed Sani Bey öldürülmüş ve sancak mutasarrıflı̆̆ına Abdulfettah Bey getirilmiştir. ${ }^{13}$

Bayezid Sancağı'ndaki aşiret, kabile ve eşrafin önerisi doğrultusunda sancakbeyi olarak atanan Abdulfettah Paşa daha sonra merkezi yönetim tarafindan "şaki" olarak kabul edilmiş ve sancak beyliğinden azledilmiştir. 1711 yılında Abdulfettah Paşa azledildikten sonra yerine Bayezid ocakzadelerinden Ahmed Bey atanmıştır. ${ }^{14}$ Bayezid sancak mutasarrıfı Ahmed Bey'den sonra 1715 tarihinde Osman Bey sancakbeyi olarak atanmıştır. Ancak Osman Bey'in Bayezid mutasarrıflığı uzun sürmemiş, Mahmud Paşa ile iktidar mücadelesine girişmişlerdir. Meydana gelen çatışmalar sonrasında 1720 tarihinde Bayezid sancakbeyliği Mahmud Paşa'ya tevcih edilmiştir. ${ }^{15}$ Osman Bey'in ise 1725 yılında Eleşkirt sancak mutasarrıflığına atandığı görülmektedir. ${ }^{16}$

Mahmud Paşa'nın sancakbeyliği uzun bir süre devam etmiştir. Bayezid ve çevre sancaklar üzerinde büyük bir otorite kurmuştur. Mahmud Paşa 1768 tarihine kadar sancakbeyliği yapmış, vefatından sonra yerine oğlu Abdulfettah Paşa geçmiştir. Abdulfettah Paşa merkezi yönetim ile yaşadığı sorunlardan dolayı beylikten azledilmiş ve yerine kardeşi/akrabası, İshak Paşa geçmiştir. Abdulfettah Paşa ise daha sonra

\footnotetext{
${ }^{8}$ Cumhurbaşkanlığı Arşiv Daire Başkanlığı Osmanlı Arşivi (BOA), Ali Emiri, Sultan Ahmed Dönemi III (A.E. SAMD III) 85/8570, 1.

${ }^{9}$ Cumhurbaşkanlığı Arşiv Daire Başkanlığı Osmanlı Arşivi (BOA), Ali Emiri, Sultan Ahmed Dönemi III (A.E. SAMD III), 196/18941.

${ }^{10}$ Ayrıntılı bilgi için bkz: Hakan Kaya, “Ahmed-i Hâni’nin Divanında Tarihi Bir Şahsiyet: Muhammed Pürbelali”, 2. Uluslararası Ahmed-i Hani Sempozyumu İslam Düşüncesinde İnsan (Doğubayazıt 28-30 Eylül 2018), ed. Abdulcebbar Kavak, (Ağrı, Ağrı İbrahim Çeçen Üniversitesi Yayınları, 2018), 182-193.

${ }^{11}$ Cumhurbaşkanlığı Arşiv Daire Başkanlığı Osmanlı Arşivi (BOA), İbnü'l Emin Tevcihat (IEE.TCT), $8 / 968$.

12 Cumhurbaşkanlığı Arşiv Daire Başkanlığı Osmanlı Arşivi (BOA), A.DVNS.MHM.d (Mühimme Defteri), nr. 111, s. 410, hk.1409.

${ }^{13}$ Cumhurbaşkanlığı Arşiv Daire Başkanlığı Osmanlı Arşivi (BOA), İbnü’l Emin Tevcihat (IEE, TCT), $23 / 2444$.

${ }^{14}$ Cumhurbaşkanlığı Arşiv Daire Başkanlığı Osmanlı Arşivi (BOA), Ali Emiri, Sultan Ahmed Dönemi III (A.E. SAMD III), 1798.

${ }^{15}$ Cumhurbaşkanlığı Arşiv Daire Başkanlığı Osmanlı Arşivi (BOA), Ali Emiri, Sultan Ahmed Dönemi III (A.E. SAMD III), 76/7632.; Başbakanlık Osmanlı Arşivi (BOA), A.DVNS.MHM.d, Nr. 129/6, 16.

${ }^{16}$ Fehamettin Başar, Osmanlı Eyalet Tevcihatı (1717-1730), (Ankara: Türk Tarih Kurumu, 1997), 118.
} 
Eleşkirt sancakbeyliğine atanmıştır. ${ }^{17}$ Bazı arşiv belgelerinde ise Abdulfettah Paşa'nın İshak Paşa'nın akrabası olduğu ifade edilmiş, ancak akrabalık derecesi belirtilmemiştir. ${ }^{18}$ İleride görüleceği üzere Abdulfettah Paşa ile İshak Paşa'nın akraba oldukları ve yurtluk-ocaklık kanunu gereği kendisinden sonra yerine kardeşi veya akrabası İshak Paşa'nın atandığı anlaşılmaktadır. Ancak birçok araştırmacının Osmanlı kanunlarındaki yurtluk-ocaklık atama usulünü veya işleyişini göz ardı ettiği görülmüştür. Çünkü Osmanlı kanunları gereği yurtluk-ocaklıkla yönetilen sancakların idarecileri merkezi yönetim tarafından azledildiğinde sancağın yönetimi önceki idarecinin ailesi veya akrabasına tevcih edilmekteydi. Aşağıdaki tabloda verilen kişiler ocakzade aile üyeleridir.

18. yüzyılda Bayezid Sancakbeylerini Gösteren Tablo

\begin{tabular}{|l|l|l|l|}
\hline Sancak & Sancakbeyi & Statüsü & Tarih \\
\hline \multirow{5}{*}{ Bayezid } & İbrahim Bey & Yurtluk-ocaklık & $?-1700$ \\
\cline { 2 - 4 } & Mehmed Sani Bey & Yurtluk-ocaklık & $1700-1706$ \\
\cline { 2 - 4 } & Abdulfettah Bey & Yurtluk-ocaklık & $1706-1711$ \\
\hline & Ahmed Bey & Yurtluk-ocaklık & $1711-1715$ \\
\cline { 2 - 4 } & Osman Bey & Yurtluk-ocaklık & $1715-1720$ \\
\cline { 2 - 4 } & Mahmud Paşa & Yurtluk-ocaklık & $1720-1768$ \\
\hline & Abdulfettah Paşa & Yurtluk-ocaklık & $1768-1775$ \\
\hline & İshak Paşa & Yurtluk-ocaklık & $1775-1799$ \\
\hline
\end{tabular}

\section{2. İshak Paşa'nın Bayezid Sancakbeyliği}

Bayezid sancakbeyi İshak Paşa, yeteri kadar ilmi çalışmaya konu olmamıştır. Bunun yanında mevcut çalışmaların doğru olmayan bazı bilgileri ihtiva ettiğini de belirtmek gerekir. Bu yanlışların başında Bayezid sancakbeyi İshak Paşa ile Çıldır valisi İshak Paşa'nın aynı kişiler olduğu düşüncesi gelmektedir. Buna göre, Bayezid sancakbeyi İshak Paşa'nın Çıldır beylerinden Hasan Paşa'nın oğlu olduğuna dair iddialar ileri sürülmüştür. Nitekim bu tür çalışmalarda İshak Paşa'nın çeşitli görevlerde bulunduktan sonra 1789 yılında vezir rütbesiyle Çıldır ve Ahıska'ya vali olarak görevlendirildiği ifade edilmiştir. Ayrıca valiliğinin ikinci yılında Şerif Paşa'nın azline sebep olması dolayısıyla bu görevden alındığ 1 ve Hasankale'ye (Pasinler) itibarı düşmüş bir şekilde gönderildiği dile getirilmektedir. ${ }^{19}$ Ancak, bu çalışmadaki bilgilerden anlaşılacağı üzere verilen bilgilerin doğru olmadığı sonucuna varılmıştır.

\footnotetext{
${ }^{17}$ Cumhurbaşkanlığı Arşiv Daire Başkanlığı Osmanlı Arşivi (BOA), Cevdet Dahiliye (C. DH), 195/9734, 3.

${ }^{18}$ Cumhurbaşkanlığı Arşiv Daire Başkanlığı Osmanlı Arşivi (BOA), Tahvil Defteri (TD), nr. 16, 144.

${ }^{19}$ Hamza Gündoğdu, Doğubayazıt İshak Paşa Sarayı, (Ankara: T.C Kültür Bakanlığı Yayınları, 1991), 17.; Mehmet İnbaşı, "Çııldır Beylerbeyleri: I. İshak Paşa ve II. İshak Paşa", Güneşin Doğduğu Yer: Doğubayazıt Sempozyumu Bildirileri, (Doğubayazıt, 13-14 Eylül 2003) ed. Oktay Belli, (İstanbul: Doğubayazıt Kaymakamlığı, Çekül Vakfı ve diğg, 2004), 183-204.
} 
$\overline{\text { Mehmed Süreyya, Sicil-i Osmani adlı eserinde Çıldırlı İshak Paşa hakkında şu ifadeleri }}$ kullanmaktadir:
“Çıldırlı İshak Paşa'nın torunu ve Hasan Paşa'nın oğludur. İshak Paşa'nın hanedandan olmakla 1205 'de (1790/91) vezir rütbesiyle Çıldır ve Ahıska valisi oldu. 1206'da (1791/92) Şerif Paşa'nın azl sebebi olarak gözden düştü ve Hasankale'de ikamet eyledi. Orada vefat etmiştir. Iradesiz, ahmaktt."20

Tartışmaya sebebiyet veren ve araştırmacıların yanlış bir nakle yönelmesine sebep olan bilgi buradan kaynaklanmaktadır. ${ }^{21}$ Fakat aynı zaman aralığında farklı sancaklarda benzer isimlerin yönetici olması gayet muhtemel bir durumdur. Nitekim Mehmed Süreyya'nın bahsettiği İshak Paşa'nın Çıldır valisi olduğunu ve Bayezid sancakbeyi İshak Paşa'nın ise Çıldır valisi ile bir ilgisinin olmadığını arşiv belgelerinde görmek mümkündür. Zira Mehmed Süreyya'nın bahsettiği İshak Paşa 1205/1790-1791 yılında Çıldır valise olmuş ve 1206/1791-1792 yılından görevinden azledilmiştir.

Bazı araştırmacılar, Çıldır Atabeylerinden İshak Paşa'nın 1701 tarihinde Çıldır valiliğine atandığını kaydetmektedir. Ayrıca bazı dönemlerde Çıldır valiliğinden azledilen İshak Paşa'nın 1748'e kadar toplam 30 yıl bir süre boyunca Çıldır valiliği yaptığı belirtilmektedir. İshak Paşa'dan sonra yerine Hac1 Ahmed Paşa ve ondan sonra da Hasan Paşa'nın Çıldır valiliğine atandığı ve İshak Paşa'nın da görevi babası Hasan Paşa'dan devraldığı dile getirilmektedir. ${ }^{22}$ Hasan Paşa'nın Mehmed Sabit ve İshak adında oğulları olduklarını gösteren arşiv kaynakları mevcuttur. Ancak Çıldır valiliği yapan İshak Paşa ile Bayezid sancakbeyliği görevini yapan İshak Paşa birbirlerinden farklı kişilerdir. İshak Paşa'nın Bayezid'de sancakbeyliği yaptığı dönemde Çıldır eski valisi Hasan Paşa'nın ortanca oğlu Mehmed Sabit Bey, Çıldır Eyaleti'nin büyük kardeşi İshak Paşa'ya tevcih edilmesi için merkezi yönetimden ricada bulunmuştur. Bundan dolayı dönemin sadrazamına durumu açıklayan bir arzuhal göndermiştir. ${ }^{23}$

Başka bir arşiv kaydında Çıldır Eyaleti'nin, muhalefet bedeli için 450, vezaret için de $150 \mathrm{kese}^{24}$ akçe mukabilinde İshak Paşa'ya tevcih edilmesine dair görüş belirtilmiştir. Ancak 150 kese akçe mansıb ve teşekkürînin rüşvet sayılacağı belirtilmiş ve nihayetinde Çıldır Eyaleti, 450 kese akçe karşılığında Hasan Paşa'nın oğlu İshak Paşa'ya tevcih edilmiştir. Belgede de anlaşıldığı üzere bu dönemde Çıldır Eyaleti valisi İshak Paşa ile Bayezid Sancağı sancakbeyi İshak Paşa farklı kişilerdir. ${ }^{25}$ Çıldır valisi İshak Paşa ile ilgili yukarıda zikredilen kaynaklar dişında çok sayıda kayda ulaşmak mümkündür. ${ }^{26}$

Ahmed Cevdet Paşa, Çıldır valisi Süleyman Paşa'nın 1205/1791'de vefatından sonra eyalet valisinin kimin olacağına dair bir toplantı yapıldığını, Hasan Paşa'nın oğlu Mehmed Sabit Bey'in eyalet valisi olarak düşünüldüğünü ancak Mehmed Sabit Bey'in bunu kabul etmediğini ve Çıldır Eyalet valiliğinin kardeşi İshak Paşa'ya tevcih

\footnotetext{
${ }^{20}$ Mehmed Süreyya, Sicil-i Osmanî, Haz. Nuri Akbayar, (İstanbul: Tarih Vakfı Yurt Yayınları, 1996), 3: 806.

${ }^{21}$ Yüksel Bingöl, “İshak Paşa Sarayı'nın Tarihlendirilmesi”, I. Uluslararası A ̆grı Dă̆l ve Nuh'un Gemisi Seтроzуити Bildirileri, Doğubayazıt, 7-11 Eylül 2005) ed. Oktay Belli, (İstanbul: Doğubayazıt Kaymakamlığı, Çekül Vakfı ve dĭğ, 2007), s. 384.

22 İnbaşı, "Çıldır Beylerbeyleri: I. İshak Paşa ver II. İshak Paşa”, 188.

${ }^{23}$ Cumhurbaşkanlığ Arşiv Daire Başkanlığı Osmanlı Arşivi (BOA), Hatt-ı Hümayun (HAT), 132/5047.

${ }^{24}$ Bir kese akçe, 17. yüzyılda yaklaşık olarak 40.000 ile 50.000 akçe gibi bir tutara denk gelmekteydi. Ayrıntılı bilgi için bkz. Baki Çakır, "Kese", Türkiye Diyanet Vakfi İslam Ansiklopedisi (İstanbul: TDV Yayınlar1, 2016), EK-2, 42-43.

${ }^{25}$ Cumhurbaşkanlığı Arşiv Daire Başkanlığı Osmanlı Arşivi (BOA), Hatt-ı Hümayun (HAT), 200/10231.

${ }^{26}$ Cumhurbaşkanlığı Arşiv Daire Başkanlığı Osmanlı Arşivi (BOA), Hatt-ı Hümayun (HAT), 186/8743.; Cumhurbaşkanlığı Arşiv Daire Başkanlığı Osmanlı Arşivi (BOA), Hatt-ı Hümayun (HAT), 187/8827.
} 
edildiğini ifade etmektedir. ${ }^{27}$ Başka bir arşiv belgesinde aynı dönemde hem Çıldır'da hem de Bayezid'de aynı adla farklı İshak Paşaların olduğu anlaşılmaktadır. Örneğin, 1180/1766-1767 tarihli bir arşiv kaydında Bayezid sancakbeyi Mahmud Paşa ve ailesinin çevre sancaklardaki bazı yerleri tasarruf ettikleri görülmektedir. İlgili belgede Mahmud Paşa'nın akrabası olarak belirtilen İshak'ın Malazgirt'e bağlı Patnos'ta bir tımar hissesine sahip olduğu anlaşılmaktadır. ${ }^{28}$

Bayezid Sancağı yöneticileri hakkında başka bir iddia da bulunmaktadır. Söz konusu iddia, Bayezid'in 1578 y1lından sonra yurtluk-ocaklık statüsüne dahil edildiğini, atabeylerin idaresine verildiğini ve bu statüsünü 19. yüzyıla kadar devam ettirdiği ifade edilmektedir. ${ }^{29}$ Bayezid ve Tev'abîha Mufassal Tahrir Defterine bakıldığında tarih ve kanunnamesi olmamakla birlikte tahririn Padişahın tuğrasından III. Murad dönemine ait olduğu anlaşılmaktadır. ${ }^{30}$ Ancak tahrirde Bayezid Sancağı'nın Çıldır Eyaleti'ne bağlandığına dair herhangi bir kayıt olmamakla birlikte Bayezid'in öncelikle Van Eyaleti'ne bir dönem Revan'a ve 17. yüzyılın ikinci yarısından itibaren de Erzurum Eyaleti'ne bağlandığı görülmektedir. ${ }^{31}$

Öncelikle İshak Paşa'nın Bayezid sancakbeyliğine dair arşiv kaydındaki belgeye bakmakta fayda vardır. 22. Cemaziyelahir 1185/ 2 Eylül $1771^{32}$ tarihinde gönderilen arşiv belgesinde

"Mahmud paşazâde mir İshak her vechle bahadır ve kârgüzâr ve hidmet-i alîyyenin tedibesine sahib-i iktidar olduğundan mîrimiranın ber vechi yurtluk-ocaklık Bayezid sancağı tevcih ve inâyet buyrulmasını Kars cânibi seraskeri olan vezir-i mükerrem Hâfiz Mustafa Paşa hazretleri iltimas itmeleriyle vezir müşarün ileyh iltimasları ve şerefbâhş sudûr olan emr-i hümâyûn mûcibince..."

ifadeleri yer almaktadır.

Arşiv kaydında İshak Paşa, Bayezid sancakbeyliğini yapabilecek kabiliyet ve vasıflara Kars seraskeri Hâfız Mustafa Paşa'nın da onayıyla layık görülmüş ve Bayezid sancakbeyliği İshak Paşa'ya tevcih edilmiştir. ${ }^{33}$ Burada İshak Paşa'nın yönetime geliş tarihi 1771 olarak ifade edilirken başka bir kayıtta ise 1775 olarak not düşülmüştür. 1771 tarihinde Bayezid Sancağı İshak Paşa'ya tevcih edilmiş olsa bile İshak Paşa'nın mutasarrıflığının uzun sürmediği veya İshak Paşa'nın sancakbeyliği görevinden azledildiği söylenebilir. Çünkü Bayezid sancakbeyliği 1775 yılında tekrar İshak Paşa'ya tevcih edilmiştir.

Bayezid sancakbeyi İshak Paşa'nın 1775 yılında göreve getirildiği ve 1799 yılında ise vefat ettiği anlaşılmıştır. Ayrıca Sicil-i Osmanî'de İshak Paşa'nın ahmak ve iradesinin zayıf biri olduğu ifade edilmiştir. Bayezid sancakbeyi İshak Paşa'nın sancakbeyliği dönemi göz önünde bulundurulduğunda kendisinin iradesiz ve ahmak kişiliğe sahip olması bir yana, aksine aksine muktedir ve müstebit biri olduğu düşünülmektedir. Arşiv

\footnotetext{
${ }^{27}$ Ahmed Cevdet Paşa, Tarih-i Cevdet, (İstanbul: Üçdal Neşriyat, 1966), III: 1396.

${ }^{28}$ Cumhurbaşkanlığı Arşiv Daire Başkanlığı Osmanlı Arşivi (BOA), Cevdet Tımar Ruznamçe (C. TZ), $168 / 8375$.

${ }^{29}$ İnbaşı, "Çı1dır Beylerbeyleri: I. İshak Paşa ve II. İshak Paşa”, 191.

30 Tapu Kadastro Genel Müdürlüğü, Kuyûd-1 Kadîme Arşivi Tahrir Defteri (TKGM.KKA.TD), Bayezid Sancă̆l ve Tevâbiha Mufassal Tahrir Defteri, nr. 199.

${ }^{31}$ Ayrıntılı bilgi için bkz. Kaya, Osmanlı-İan Sınırında Bir Serhad Sancă̆l: Bayezid (1578-1648).

${ }^{32}$ Doktora tezimde 1771 yılı yerine 1777 yazılmış, yani 1 yerine sehven 7 yazılmıştır.

33 Cumhurbaşkanlığı Arşiv Daire Başkanlığı Osmanlı Arşivi (BOA), Cevdet Dahiliye (C. DH), 202/10061.
} 
kayıtlarına göre sancak mutasarrıflı̆̆ı döneminde İshak Paşa'nın Diyadin, Şelve ve Eleşkirt sancakbeyleri üzerinde mutlak anlamda bir otorite kurduğu anlaşılmaktadır. ${ }^{34}$

1775 yılında Abdulfettah Paşa'nın vefat etmesinden sonra Bayezid mutasarrıflığına İshak Paşa getirilmiştir. Bütün bu kayıtlardan hareketle İshak Paşa'nın 1791-1792 Çııldır ve Ahıska'ya vali olarak atanma durumu ile Bayezid sancakbeyliğine atanma meselesi birbirine karıştırılmaktadır. Çünkü kaynaklara bakıldığında Bayezid mutasarrıfı İshak Paşa'nın bu dönemde sancak mutasarrıfı olduğu ve bu görevini 1799 yılına kadar sürdürdüğü görülmektedir. Atandığı tarihten ölümüne kadar başka bir sancakbeyliği ve eyalet valiliği görevine atandığına dair herhangi bir kayıt bulunmamaktadır.

Yukarıda kaydedilenin yanı sıra İshak Paşa'nın kapı kethüdası ve Dergâh-1 Âli kapıcıbaşlarından Ahmed Ağa'nın tahriratına bakıldığında İshak Paşa'nın Bayezid eski sancakbeyi Mahmud Paşa'nın oğlu olduğu görülmektedir. Söz konusu arşiv kaydında Bayezid Sancağı'nın öteden beri yurtluk-ocaklık olarak yönetildiği ifade edilmektedir. Ayrıca kayıttan anlaşıldığına göre Eleşkirt, Diyadin Şelve ve Malazgirt sancakbeylerinin azli ve nasbı Bayezid sancakbeylerinin arzı ve reyi ile olmaktaydı. Arşiv belgesi Bayezid sancakbeyi İshak Paşa'nın Çıldır valisi İshak Paşa'nın farklı kişiler olduğunu destekler mahiyette bilgi sunmaktadır. Kethüda dilekçeye "Paşa-i mümâ ileyh (İshak Paşa) kullarının pederi Mahmud Paşa vefatından sonra...." şeklinde ifadeleri not düşmüş ve adı geçen sancakbeylerinin heva ve heveslerine kapılarak kendi başlarına hareket ettiklerinden şikayet etmiştir. ${ }^{35}$ Yukarıdaki ifadeden anlaşıldığ üzere İshak Paşa Hasan Paşa'nın değil, Mahmud Paşa'nın oğludur.

Arşiv kayıtlarına bakıldığında İshak Paşa'nın “ahmak veya iradesiz” bir kişiliğe sahip olmak bir yana, bunun tam aksine muktedir bir şahsiyete haiz olduğu anlaşılmaktadır. Bu bağlamda Bayezid mutasarrıfı İshak Paşa'nın idareci yönü üzerinde durmakta fayda vardır. İshak Paşa, yönetimde kaldığı süre boyunca sancak dahilinde bulunan aşiretlerle, çevre sancak beyleriyle ve İran hanlarıyla yoğun bir mücadeleye girişmiştir. İshak Paşa'nın bu kadar geniş bir kesimle yoğun mücadeleye girişmesinin nedeni bölgede otoritesini güçlendirmek ve bu kesimlere nüfuzunu kabul ettirmek istemesinden olsa gerektir

İshak Paşa kendinden önceki sancakbeyleri gibi Bayezid'i yurtluk-ocaklık olarak yönetmiştir. Sancakbeyliği yaptığı süre zarfında merkeze hakkında çok sayıda şikâyet yapılmıştır. Kendisi hakkında yapılan bütün şikâyetler doğru olmamakla birlikte bunların önemli oranda büründüğü muktedir kişiliğinden kaynaklandığı düşünülebilir. Öte yandan Bayezid sancakbeyi İshak Paşa'nın (ö. 1799) birçok olaya müdahil olmasına rağmen merkezi otoritenin kendisine karşı herhangi bir cezaî yaptırımda bulunmaması dikkate değerdir. İshak Paşa, Eleşkirt Sancağı eşrafından çok sayıda kişiyi öldürmüş veya öldürmüştür. Öldürülenler arasında Eleşkirt mutasarrıfı Abdi Paşazade, Muhammed Bey, kardeşi Ali ve Süleyman Beyler, Süleyman Ağa, Süleyman Ağa'nın oğlu Ali Ağa ve amcazadesi Yakup Ağa, Müderris Abdulgaffur Bey, Ova Subaşısı Süleyman Ağa ve Hamur beyi İbrahim Bey gibi şahıslar yer almaktadır. ${ }^{36}$ Ayrıca İshak Paşa'nın Eleşkirt hanedanından yukarıdaki şahsiyetler dışında 45 kişiyi daha öldürdüğü iddia edilmiştir. ${ }^{37}$

\footnotetext{
${ }^{34}$ Cumhurbaşkanlığı Arşiv Daire Başkanlığı Osmanlı Arşivi (BOA), Cevdet Dahiliye (C. DH), 1-3.

35 Cumhurbaşkanlığı Arşiv Daire Başkanlığı Osmanlı Arşivi (BOA), Cevdet Dahiliye (C. DH), $305 / 15208,1$

${ }^{36}$ Cumhurbaşkanlığı Arşiv Daire Başkanlığı Osmanlı Arşivi (BOA), Hatt-ı Hümayun (HAT), 63/2753-G.

${ }^{37}$ Yakup Karataş, Bayezid Sancağı ve İdarecileri (1700-1914), (İstanbul: Kitapevi, 2014), 36.
} 
İshak Paşa'nın eşraftan ve ahaliden bu kadar çok sayıda kişiyi öldürtmesi, paşanın gücünü ve tegallübünü göstermektedir. O iktidarını elde tutmak için çok sayıda insanın hayatına kastetmiş ve rakiplerini bertaraf etmeye çalışmıştır. Devletin, sınırda bulunan ve halk üzerinde güçlü bir iktidar kuran sancakbeyini tam olarak denetim altına aldığını söylemek mümkün değildir. Bu durum 18. yüzyılın sonlarına doğru devletin içinde bulunduğu sosyal ve siyasal durumla ilintilidir.

İshak Paşa'nın bu şekilde cüretkâr davranarak çok sayıda kişiyi öldürmesi/öldürtmesi ve herhangi bir şekilde cezalandırılmaması, görevinden azledilmemesi onun İran'a tabi olma ihtimaline karşı bir önlem alma şeklinde yorumlanmıştır. ${ }^{38}$ Ancak İshak Paşa'nın cezalandırılmaması veya görevinden azledilmemesinin tek nedeni İran'a sı̆̆ınma ihtimali ile izah edilemez. Çünkü İshak Paşa'nın cezalandırılmaması ve görevden azledilmemesi paşanın iktidarı süresince nüfuzlu ve güçlü bir iktidara sahip olduğunu göstermiştir.

Başka arşiv kayıtlarında da İshak Paşa'nın Eleşkirt, Diyadin, Hamur ve Malazgirt sancakları mutasarrıflarını baskı altına aldığı, adı geçen sancaklardan bazılarını kendisine ve oğullarına ocaklık veya malikâne olarak tevcih ettirdiği ve "ocakzade" olarak isimlendirilen yerel ailelere türlü zulümler ettiği belirtilmiştir. ${ }^{39}$

İshak Paşa'nın oğullarına Tekman, Hınıs ve Malazgirt ${ }^{40}$ sancaklarını malikâne olarak tevcih ettirmesi, Diyadin ve Eleşkirt gibi sancakların mutasarrıflarını baskı altında tutması, yeri geldiğinde İran'ın bazı bölgelerine saldırması gibi eylemleri paşanın muktedir ve siyasi olarak güçlü bir kişi olduğunu göstermektedir. Ayrıca Bayezid'in İran serhaddinde bulunması sancak mutasarrıflarının kontrolünü zorlaştırmıştır. Bu sebeplerden ötürü merkezi otorite, bazen uç bölgelerdeki mutasarrıfların reayaya uygulamış olduğu zorba/hukuksuz/müstebit yönetime pek müdahale etmemiştir. ${ }^{41}$

Bayezid'de bulunan ahalinin Celali ve Sipki gibi aşiretlerden rahatsız olduklarına dair çok sayıda arşiv kaydına ulaşılmıştır. 1197/1783 tarihinde sancakta bulunan ulema ve eşrafın İshak Paşa hakkında yaptıkları şikâyette söz konusu sene içerisinde Celali ve Sipki aşiret üyelerinin dört köyden 1.000 kadar büyükbaş ve 2.000'den fazla küçükbaş talan ettikleri ifade edilmiştir. Merkeze şikayette bulunanlar bu durumu sancakbeyi İshak Paşa'ya ilettiklerini, İshak Paşa'nın gasp edilen hayvanlardan cüz'i bir kısmını kendilerine iade ettiğini, geriye kalan kısmını ise zimmetine geçirdiğini iddia etmişlerdir. ${ }^{42}$ Ayrıca Daşanlu taifesinden bazı kimselerin sınır ihlalinde bulunarak Bayezid'e tabi Köroğlu Kalesi'ne yerleşerek etraftaki reayaya zarar verdikleri belirtilmiştir. Buna rağmen İshak Paşa'nın adı geçen taifeyi cezalandırmadığ edilmiştir. Bunun yanı sıra Bayezid'de bulunan Kürt aşiretleri de Daşanlu taifesinden Ramazan adlı kişiyle birlikte Kars köylerinden Digor'a baskın düzenleyerek burada bulunan reayanın mallarını yağmalamış ve 7 kişiyi öldürmüşlerdir. Bayezid'deki ulema ve eşraf bu olaylardan dolayı İran serhaddinde bulunan ahalinin perişan olduğunu

\footnotetext{
38 İnbaşı, "Çıldır Beylerbeyleri: I. İshak Paşa ve II. İshak Paşa", 193.

${ }^{39}$ Cumhurbaşkanlığı Arşiv Daire Başkanlığı Osmanlı Arşivi (BOA), Cevdet Dahiliye (C. DH), 34/1679.

${ }^{40}$ Malazgirt Sancağı'nda bazı yerler tarihi süreç içerisinde farklı statüde tasarruf edilmiştir. 1155/1742 yılında Erzurum seraskeri Ali Paşa'ya malikâne olarak idare etmiştir. 1165/1751'de İbrahim'e yurtlukocaklık olarak verilmiştir. 1208/1793'te ise İshak Paşa'nın oğulları olan Mahmud Bey ve İbrahim Bey’e tevcih edilmiştir. Bkz. Cumhurbaşkanlığı Arşiv Daire Başkanlığı Osmanlı Arşivi (BOA), Cevdet Dahiliye (CDH), 68/3392, 2.

${ }^{41}$ Cumhurbaşkanlığı Arşiv Daire Başkanlığı Osmanlı Arşivi (BOA), Cevdet Dahiliye (C. DH), 38/1866.; Cumhurbaşkanlığı Arşiv Daire Başkanlığı Osmanlı Arşivi (BOA), Cevdet Dahiliye (C. DH), 68/3392.

${ }^{42}$ Cumhurbaşkanlığı Arşiv Daire Başkanlığı Osmanlı Arşivi (BOA), Hatt-ı Hümayun (HAT), 12/448-M.
} 
belirterek, merkezi yönetimin İshak Paşa'nın yapmış olduğu baskı ve zulme müdahalede bulunmasını ve bu zulümden kendilerini kurtarmalarını talep etmişlerdir. ${ }^{43}$

Reaya sancak yöneticilerinin değişikliğinden olumsuz şekilde etkilenmiştir. Örneğin Hınıs ve Tekman sancakları malikâne olarak tasarruf edilmeden önce yurtluk-ocaklık olarak yönetilmiştir. Ancak daha sonra İshak Paşa ile Veli Paşa adı geçen yerleri malikane olarak tasarruf etmişlerdir. İshak Paşa ile Veli Paşa arasında Hınıs ve Tekman'ın sıklıkla el değiştirmesi paşalar arasında güç ve rekabet ilişkisini doğurmuş ve daha sonraki yıllarda büyük bir sorun olarak devam etmiştir. Örneğin, İshak Paşa, Hınıs ve Tekman sancaklarını oğullarına tevcih ettirmiş, ancak buralar daha sonra İshak Paşa'dan alınarak tekrar Veli Paşa ve kardeşinin yönetimine verilmiştir. 1793 yılında Veli Paşa ve Mehmed Paşa'nın halka zulmettiği ve mallarına zorla el koyduğu, reayanın gördüğü bu baskılardan dolayı çevre sancaklara dağıldığı kaydedilmiştir. Bu sebepten ötürü adı geçen sancaklar Veli Paşa ve kardeşinden alınarak İshak Paşa'nın çocuklarına tekrar tevcih edilmiştir. Malikane olarak idare edilen sancakların yönetimlerinin el değiştirmesi beylerin birbirlerinin mallarını gasp etmelerini beraberinde getirmiştir. ${ }^{44}$ Ayrıca sancaklar üzerinde iktidar ve menfaat mücadelesi halkın bulundukları yerlerden göç ederek başka yerlere gitmesine sebep olmuştur. Reayanın bu yer değişimi sancak dahilinde sosyoekonomik sıkıntıların meydana gelmesine sebebiyet vermiştir.

1212/1798 tarihinde Erzurum valisi Ziya Yusuf Paşa, Bayezid sancakbeyi İshak Paşa'nın sancak yönetimi ve çevre sancakbeyleriyle olan münasebeti hakkında merkeze bir rapor göndermiştir. Raporda İshak Paşa ve oğullarının Eleşkirt, Hınıs, Tekman, Malazgirt, Hamur ve Diyadin sancaklarını malikâne olarak tasarruf ettikleri belirtilmiştir. Raporda İshak Paşa'nın hâkimiyet alanını genişletmek için Erzurum ve Kars taraflarına Sipki aşiretini, Van taraflarına ise Haydaran aşiretini gönderdiği ifade edilmiştir. İshak Paşa'nın güç ve kuvvet olarak diğer sancakbeylerinden üstün olduğu, diğer sancak beylerini bir bir hâkimiyeti altına aldığı ve reayaya büyük haksızlıklar yaptığı vurgulanmıştır. Raporda Diyadin ve Hamur sancaklarının İshak Paşa'ya bırakılmasının, Eleşkirt ve Malazgirt sancaklarının yurtluk-ocaklık olarak eski sahiplerine verilmesinin daha uygun olacağı ifade edilmiştir. ${ }^{45}$

İshak Paşa'nın Malazgirt Sancağı ile ilgili durumu hakkında da merkeze rapor gönderilmiştir. Raporda Malazgirt sancakbeyliğinin Murat Paşa'ya verilmesinin daha uygun olacağı beyan edilmiştir. Malazgirt Sancağı'nın Murad Paşa'ya tevcih edilmesinin sebebi, Malazgirt'in İshak Paşa'nın kontrolündeki Bayezid'den uzak olması ile izah edilmiştir. Dolayısı ile İshak Paşa'nın Malazgirt'i kontrol altında tutamayacağı, Bayezid Sancağı'nı idare ettiği günden beri cizye vergilerini göndermemesi, buna karşın Murad Paşa'dan cizye vergisini tahsil etmenin daha kolay olacağı belgede belirtilen hususlardır. Bununla birlikte Murad Paşa'nın, İshak Paşa'ya karşı sancağı muhafaza etmesinin mümkün olmadığı da dile getirilmiştir. Çünkü İshak Paşa'nın sahip olduğu askeri kuvvet ve şecaat açısından Murad Paşa'dan üstün olduğu ifade edilmiştir. Bunun yanı sıra Osmanlı serhaddinde İran ile problemlerin halen devam ettiği, bu sebeplerden ötürü Malazgirt Sancağı'nın, Eleşkirt Sancağı gibi İshak Paşa'dan alınarak Murad Paşa ve oğulları Mirza, Mehmed ve Selim Beylere verilmesi gerektiği yönünde fikir beyan edilmiştir. Devlet, raporda belirtilen hususları dikkate almış ve Malazgirt'i Murad

\footnotetext{
${ }^{43}$ Cumhurbaşkanlığı Arşiv Daire Başkanlığı Osmanlı Arşivi (BOA), Hatt-ı Hümayun (HAT), 12/448-M.; Hatt-ı Hümayun (HAT), 12/448-L.

${ }^{44}$ Cumhurbaşkanlığı Arşiv Daire Başkanlığı Osmanlı Arşivi (BOA), Cevdet Maliye (C ML), 8665.

${ }^{45}$ Cumhurbaşkanlığı Arşiv Daire Başkanlığı Osmanlı Arşivi (BOA), Cevdet Dahiliye (C. DH), 68/3392.
} 
Paşa'ya tevcih etmiştir. ${ }^{46}$ Bu bağlamda Malazgirt Sancağı'nın kontrolü meselesi İshak Paşa ile Murad Paşa arasındaki mücadelenin şiddetlenmesine sebebiyet vermiştir.

Yukarıda ifade edildiği gibi İshak Paşa'nın sancakbeyliği sırasında kendisi hakkında çok sayıda şikâyete rastlanmıştır. Çünkü İshak Paşa, Bayezid sancakbeyliği ile iktifa etmemiş, güç mücadelesine girişerek Diyadin, Hamur, Eleşkirt, Hınıs, Tekman ve Malazgirt sancaklarını kendi çocukları ve akrabalarına, merkezi devletin onayı alınmadan veya kendisi ve yakınları hakkında kamuoyu oluşturarak, tevcih ettirmiştir. Ayrıca İshak Paşa'nın Sipki aşiretiyle birlikte Erzurum ve Kars taraflarında olan yerleşik ahaliyi yerlerinden göç ettirdiği ve 1.500 baş inek ve mandalarını gasp ettirdiği dile getirilmiştir. Bunun yanı sıra Eleşkirt sancakbeyinin seçimine müdahale ettiğgi, Hınıs ve Tekman sancakları dolayısıyla Erzurum valileri ile sorunlar yaşadığı beyan edilmiştir. 47

Osmanlı Devleti'nin yurtluk-ocaklık sancakları merkezi otoritenin dikkatinden uzak tutmadığı ve bu sancaklarda meydana gelen gelişmeleri beylerbeyi ve kadılar aracılığgyla takip etmeye çalışıtığ kontrolün serhad bölgelerinde istenilen düzeyde olduğu söylenemez. Yukarıdaki örnekte anlaşıldığı üzere beylerbeyi veya kadının İshak Paşa'ya karşı, kayda değer bir önlem alacak güçte oldukları söylenemez. Gerekli önlemler alınamadığı için İshak Paşa Bayezid'de otoriter bir politika izliyor, devletin kendisine ciddi bir yaptırımda bulunmaması İshak Paşa'yı nüfuz ve otoritesini sağlamada daha da serbest bırakıyordu. Devletin İshak Paşa'ya karşı affetme yolunu tercih etmesinin bölgenin stratejik bir öneme sahip olması, paşanın bölge halkı üzerindeki etkisi veya müstebit bir yönetim uygulaması, devletin içinde bulunmuş olduğu sosyal ve siyasal durum ve İran'la diplomatik bir krizin yaşanmasının önüne geçmek gibi sebeplerden kaynaklandığı ileri sürülebilir. ${ }^{49}$

Başka bir arşiv kayd1, 1798'de Erzurum valisi Abdullah Paşa'ya gönderilen bir hükümdür. Buna göre İshak Paşa'nın Revan'a birkaç kez saldırıda bulunduğu ve köylerde bulunan reayaya zarar verdiği dile getirilmiştir. Anlaşıldığı kadarıyla İshak Paşa saldırı sonucu bazı kimseleri esir almış, 5.000-6.000 asker ile Revan'ın Sürmeli nahiyesinde ikamet etmeye başlamıştır. Bu duruma Revan hanının karşılık vermesiyle bölgede büyük bir çatışma çıkmış ve bu sebepten ötürü merkezi yönetim Erzurum eyalet valisinden bu karışıklığı sonlandırmasını ve tarafların yaptığ saldırıyı durdurarak muhtemel büyük bir mücadelenin önüne geçmesini emretmiştir. ${ }^{50}$

Semavi Eyice, İshak Paşa'nın yaptırdığı sarayla Osmanlı hanedanı ile rekabete girişmek düşüncesinde olduğunu, İran'dan Osmanlı başkentine giden İran elçisinin abartılı sözleriyle bu rekabeti kızıştırdığını ve İshak Paşa'nın gözden düşerek Hasankale'ye sürgün edildiğini ve burada öldüğünü ifade etmektedir. ${ }^{51}$ Daha önce de ifade edildiği gibi İshak Paşa 1799 yılına kadar iktidarda kalmış ve ölümünden sonra yerine oğlu Mahmud Paşa geçmiştir. Ayrıca İshak Paşa'nın Hasankale'ye sürgün edildiğine dair herhangi bir kayda rastlanmamıştır. Burada Bayezid sancakbeyi İshak Paşa ile Çıldır

\footnotetext{
${ }^{46}$ Cumhurbaşkanlığı Arşiv Daire Başkanlığı Osmanlı Arşivi (BOA), Cevdet Dahiliye (C. DH), 68/3392.

${ }^{47}$ Cumhurbaşkanlığı Arşiv Daire Başkanlığı Osmanlı Arşivi (BOA), Hatt-ı Hümayun (HAT), 63/ $2753-G$.

48 Orhan Kılıç, “Ocaklık Sancakların Osmanlı Hukukunda ve İdari Tatbikattaki Yeri”, Fırat Üniversitesi Sosyal Bilimler Dergisi, 11/ 1, (Elazı̆̆, 2001). 265-267.

${ }^{49}$ Karataş, Bayezid Sancă̆ $\breve{l}$ ve İdarecileri (1700-1914), 25.

${ }^{50}$ Cumhurbaşkanlığı Arşiv Daire Başkanlığı Osmanlı Arşivi (BOA), Cevdet Hariciye (C. HR), 2256.

51 Semavi Eyice, "İshak Paşa Saray1", Türkiye Diyanet Vakfi İslam Ansiklopedisi (İstanbul: TDV Yayınlar1, 2000), 22: 542.
} 
valisi İshak Paşa'nın karıştırıldığı anlaşılmaktadır ve bunun sebebi ise söz konusu kişilerin aynı yöneticiler olarak düşünülmesinden kaynaklanmaktadır.

18 yüzyılda imparatorluğun İran serhaddinde ayanlığa benzer bir yapının Bayezid Sancağı özelinde ve İshak Paşa'nın şahsında mücessem hale gelmiştir. 18. yüzyıldan sonra Adana'daki Kozanoğlulları, Yozgat'taki Çapanoğulları inşa ettikleri siyasi yapılarıyla ayanlığın yerel mimari ve siyasetinin temsilcisi konumuna gelmişlerdir. ${ }^{52} \mathrm{Bu}$ bağlamda Bayezid'de İshak Paşa'nın ataları ve hanedanı sancak yöneticiliğinde ayanlığa benzer bir yapıyla (yurtluk-ocaklık statüsüyle) etkinliklerini korumuşlardır. İnşa ettirdiği sarayıyla İshak Paşa ve hanedanı Osmanlı sınır eyaletinin muktedir ayanıydı ve sarayı da bu olgunun günümüze kalan muhteşem abidesiydi.

\section{3. İshak Paşa'ın Abdulfettah Paşa ile Akrabalığı}

İshak Paşa ile ilgili meselenin daha iyi anlaşılması için Abdulfettah Paşa ile akrabalık bağına bakmakta fayda vardır. Bayezid Sancağı ile ilgili arşiv kayıtlarına dikkatlice bakıldığında Abdulfettah Paşa'nın Mahmud Paşa'nın oğlu olduğu açık bir şekilde görülmektedir. Örneğin 898 numaralı Tapu Tahrir Defteri kaydında Maku 1725-26 senesinden 1728-29 senesine kadar yurtluk-ocaklık olarak Bayezid sancakbeyi Mahmud Paşa'nın oğlu Abdulfettah Paşa'nın tasarrufundaydı. Ekrad beylerine yurtluk-ocaklık olarak verilen Makü'nün 1141/1728-29 tarihinden itibaren bu statüsü kaldırılarak Van Eyaleti mukataasına aktarıldığı ifade edilmektedir. ${ }^{53} 7$ Zilkade 1182/15 Mart 1769 tarihli başka bir arşiv kaydında "Bayezid sancă̆ sen ki mîrimiran muma ileyhsin pederin mütevvefa Mahmud Paşa mahlulünde sana tevcih ve ihsanım olmağla"...ifadesi yer almaktadir. ${ }^{54}$

Bayezid sancakbeyi Mahmud Paşa vefat ettikten sonra yerine oğlu Abdulfettah Paşa geçmiştir. Abdulfettah Paşa'nın bazı kayıtlarda 1775 yılında, bazı kayıtlarda ise 1783 yılında vefat ettiği ifade edilmektedir. Abdulfettah Paşa'nın Bayezid sancakbeyliğinden sonra tekrar Eleşkirt sancakbeyliğine atanması ile ilgili belgeler arasında ihtilaflar bulunmaktadır. Ancak Bayezid ve Eleşkirt beylerinin genellikle birbirlerinin akrabası olduğu bilinmektedir.

16 Numaralı Tahvil defterinde Bayezid mutasarrıfı İshak Paşa'nın atanması aşağıdaki şekilde kaydedilmiştir:

"Livâ-i mezbûrede ber-vech-i yurtluk ve ocakllk mutasarrif olan Abdulfettah Paşa fevt olup livâ-i mezbûr mahlül ve İshak Bey mütevvefa-i merkûmun akrabasından yarar ve işgüzâr ve her vecihle mahall ve müstahak ve sezâvar-l inâyet olduğuna binaen vezir-i mükerrem Erzurum valisi saâdetlü Ali Paşa hazretlerinin tahriri ve iltiması mucibince ber-vech-i yurtluk ve ocaklik tevcih olunmuştur. Fi. 4 L. 189."55

Belgede Abdulfettah Paşa ile İshak Paşa'nın akraba olduğu ifade edilmiştir. Başka bir belgede ise İshak Paşa'nın, Mahmud Paşa'nın oğlu olduğu beyan edilmiştir. ${ }^{56}$ Belgelere bakıldığında Bayezid sancakbeyi İshak Paşa'nın Hasan Paşa'nın oğlu olmadığı,

\footnotetext{
52 Ayrıntılı bilgi için bkz. Ali Yaycioğlu, Partners of the Empire: The Crisis of the Ottoman Order in the Age of Revolutions, (California: Stanford Üniversity Press, 2016).

${ }_{53}$ Cumhurbaşkanlığı Arşiv Daire Başkanlığı Osmanlı Arşivi (BOA), Tapu Tahrir Defteri, (TT. d). nr. 898,6

${ }^{54}$ Cumhurbaşkanlığı Arşiv Daire Başkanlığı Osmanlı Arşivi (BOA). Cevdet Dahiliye (C. DH), 111/5546.

${ }^{55}$ Cumhurbaşkanlığı Arşiv Daire Başkanlığı Osmanlı Arşivi (BOA), Tahvil Defteri, nr. 16, s. 144. Aynı defterde 1191/1777 tarihli başka bir kayıtta İshak Paşa'nın yarar ve işgüzar biri olduğu dile getirilmiştir. Bunun yanı sıra iktidar sahibi ve üzerine aldığı vazifeleri hakkıyla yerine getiren biri olarak zikredilmiştir.

${ }^{56}$ Cumhurbaşkanlığı Arşiv Daire Başkanlığı Osmanlı Arşivi (BOA), Cevdet Dahiliye (C. DH), 1.
} 
Mahmud Paşa'nın oğlu veya akrabası olduğu anlaşılmaktadır. Bazı belgelerde her ne kadar İshak Paşa'nın akrabası olarak ifade edilmiş olsa bile Mahmud Paşa'nın oğlu olduğu kuvvetle muhtemeldir.

Bayezid ile Eleşkirt sancakbeyleri arasında sürekli devam edegelen bir çatışma ve rekabet söz konusu olmuştur. Mesela 1774 tarihli bir kayıtta Bayezid sancakbeyi Abdulfettah Paşa'nın oğlu Ali Bey'in babasından aldığ 1 güç ve kudretle Eleşkirt sancakbeyliğini zorla zapt ettiği ifade edilmiştir. Merkezi yönetim, Eleşkirt sancakbeyliğinin daha önce Mahmud Paşa'nın oğlu Abdullah Bey'e yurtluk-ocaklık olarak tevcih edildiğini, reayanın hoşnutluğundan dolayı tekrar kendisine tevcih edilmesini ve Bayezid sancakbeyinin (Abdulfettah Paşa) Eleşkirt sancakbeyliğine müdahalede bulunmamasını emretmiştir. ${ }^{57}$ Kayıtta görüldüğü üzere Bayezid ve Eleşkirt sancaklarının yöneticileri aynı aileden yani kardeş olan beylerdir. Bu beylerin çoğu zaman birbirleriyle mücadele halinde oldukları görülmektedir.

14 Kasım 1783 tarihli belgede sancak mutasarrıfı Abdulfettah Paşa'nın vefatından sonra yerine oğlu Ali'nin geçtiği belli bir süre sonra Ali Paşa'nın da vefat ettiği dile getirilmiştir. Bayezid sancakbeyi İshak Paşa'nın, Eleşkirt sancakbeyliğini oğlu Mahmud Paşa'ya tevcih ettirdiği ifade edilmiştir. Burada Eleşkirt mutasarrıflığının Abdulfettah Paşa'nın oğularının hakkı olduğu vurgulanmıştır. Sancağın ileri gelenlerinden 56 kişi merkezi yönetime arzuhal göndererek Halil Bey'in emmizadesi (ammuzadesi) Mahmud Paşa'nın halka zulmettiğinden kendisinin azledilmesini, yerine Abdulfettah Paşa'nın oğlu Halil Bey'in sancak mutasarrıfı olmasını istemişlerdir. ${ }^{58}$ Belgeden anlaşılacağı üzere Bayezid, Eleşkirt sancakları yurtluk-ocaklık olarak aynı aile üyeleri tarafından yönetilmiştir. Bayezid ve Eleşkirt sancakları İshak Paşa ve kardeşlerinin çocukları arasında mücadele alanları olmuştur.

\section{SONUÇ}

Osmanlı kanunnamelerine göre yurtluk-ocaklık statüsüyle yönetilen yerlerde sancakbeyi öldüğünde veya azledildiğinde yerine aynı aileden biri geçmekteydi. $\mathrm{Bu}$ statüyle yönetilen sancakların idarecilerine bakıldığında, bu idareciler "ocakzadeliler" ismiyle adlandırılmıştır. Bayezid, Diyadin, Şelve ve Eleşkirt sancakları da yurtluk ocaklık olarak yönetilmiş ve adı geçen sancaklarda ocakzadeli aileler yoğun bir güç ve rekabet mücadelesinde bulunmuştur. Bayezid diğer sancaklara göre daha çok öne çıkmış ve Bayezid sancak yöneticiliğini yapan sancakbeyleri, diğer sancaklara akrabalarından olan kişilerin atanmasında etkili olmuştur. Bu bağlamda buralarda kendi hakimiyet ve nüfuzlarını tesis etmeye çalışmışlardır.

Yapılan araştırmalarda 18. yüzyılın son çeyreğinde Bayezid sancakbeyliğini yapan İshak Paşa'nın Çıldır atabeylerinden olduğu iddia edilmiştir. Ancak konu ile ilgili yapılan ayrıntılı araştırmada Bayezid sancakbeyi Mahmud Paşa'nın oğlu (bazı yerlerde akrabası) İshak Paşa ile Çıldır valisi Hasan Paşa'nın oğlu İshak Paşa'nın aynı kişiler olmadığı, Bayezid sancakbeyi İshak Paşa'nın Çıldır atabeyleriyle herhangi bir ilgisinin olmadığı anlaşılmıştır. Yukarıda da ifade edildiği gibi bu tarihi kişiliklerin ayrı şahıslar oldukları arşiv kaynakları ışında ortaya konulmaya çalışılmıştır. Sicilli Osmani'den

\footnotetext{
57 Cumhurbaşkanlığı Arşiv Daire Başkanlığı Osmanlı Arşivi (BOA). Erzurum Ahkam Defterleri (A.DVNS.AHK. ER), nr. 5, 285.

${ }^{58}$ Cumhurbaşkanlığı Arşiv Daire Başkanlığı Osmanlı Arşivi (BOA). Cevdet Dahiliye (C. DH), 195/9734, 3.
} 
yapılan alıntıda İshak Paşa'nın ahmak biri olduğu ve Hasankale'ye sürgün edildiği ifade edilmiştir. Ancak yapılan araştırmada İshak Paşa'nın 1799 tarihine kadar Bayezid sancakbeyliği görevini yaptığı ve çevre sancakbeylerine göre daha kudretli bir kişiliğe sahip biri olduğu anlaşılmıştır ve kanıtlarıyla ortaya konulmuştur. Bu bağlamda İshak Paşa yerel Kürt beylerinden olup, Diyadin, Şelve ve Eleşkirt sancakbeylerine göre daha muktedir bir yönetim sergilemiştir.

Yukarıdaki arşiv kayıtlarından anlaşıldığı üzere Abdulfettah Paşa'nın Mahmud Paşa'nın oğlu olduğu aşikardır. Bu bağlamda Bayezid ile ilgili kayıtlara bakıldığında Abdulfettah Paşa ile İshak Paşa'nın kardeş veya akraba oldukları görülmektedir. Buna ek olarak Bayezid ve Eleşkirt ile ilgili bütün kayıtlara bakıldığında Çıldır valisi Hasan Paşa ile Bayezid mutasarrıfi/sancakbeyi Mahmud Paşa'nın oğlunun/akrabasının isim benzerliğinden veya ayrıntılı bir araştırma yapılmamasından dolayı karıştırıldığını söyleyebiliriz. Böylece Bayezid sancakbeyi İshak Paşa ile Çıldır valisi İshak Paşa'nın farklı tarihi kişilikler olduğu anlaşılmaktadır.

Abdulfettah Paşa Eleşkirt mutasarrıflığı yapmış, ancak gerek merkezi yönetim ile gerekse reaya ile yaşamış olduğu sorunlardan dolayı Eleşkirt sancakbeyliğinden azledilmiştir. Abdulfettah Paşa babası Mahmud Paşa'nın 1769 yılında vefat etmesinden sonra Bayezid sancakbeyliğine getirilmiştir. Abdulfettah Paşa bazı arşiv kayıtlarına göre vefat etmiş bazılarına göre ise Bayezid sancakbeyliğinden azledilerek tekrar Eleşkirt sancakbeyliğine atanmıştır. $\mathrm{Bu}$ görevini 1783 yılına kadar devam ettirmiştir. Kendisinden sonra Bayezid sancakbeyliğine aynı aileden olan İshak Paşa getirilmiştir. Bayezid ve Eleşkirt sancaklarında aynı aile üyeleri arasında daha önceden süregelen beylik mücadelesi bu dönemde de devam etmiştir.

Abulfettah Paşa'nın ölümünden sonra yurtluk-ocaklık kanunu gereği Eleşkirt sancakbeyliği görevi oğullarına geçmiştir. Ancak İshak Paşa gerek Erzurum valileriyle gerekse merkezi yönetimle sağlam ilişkiler kurmuştur ve oğlu Mahmud Paşa' ya Eleşkirt beyliği tevcih edilmiştir. Daha sonra Eleşkirt Sancağı'nın kabile, aşiret ve eşrafından bazı kimseler devlet merkezine gönderdikleri arzuhalle İshak Paşa'nın oğlu Mahmud Paşa'yı istemediklerini, onun yerine Abdulfettah Paşa'nın oğlu Halil Bey'i istediklerini ifade etmişlerdir. Merkezi yönetim gönderilen dilekçeyi dikkate almış ve Halil Bey’i Eleşkirt sancakbeyliğine atamıştır. Yukarıdaki metinde de ifade edildiği gibi özellikle Bayezid, Eleşkirt sancaklarına idareciler genellikle aynı aileden olan kişiler atanmıştır. Yurtluk-ocaklık statüsüne sahip olan sancaklarda uygulanan bu sistem her iki sancakta da uygulanmış ve bu uygulama Tanzimat sonrası taşra teşkilatının dönüşümüne kadar kadar devam etmiştir.

\section{KAYNAKÇA}

\section{A- Arşiv Kaynakları ve Birincil Kaynaklar}

Cumhurbaşkanlığı Arşiv Daire Başkanlığı Osmanlı Arşivi (BOA). Mühimme Defterleri (A.DVNS.MHM.d). nr. 111, 129.

Cumhurbaşkanlığı Arşiv Daire Başkanlığı Osmanlı Arşivi (BOA). Cevdet Dahiliye (C. DH). 111/5546.; 195/9734.; 305/15208.; 38/1866.; 68/3392.; 34/1679.; 202/10061.; Cevdet Hariciye (C. HR). 2256.; Cevdet Maliye (C. ML). 8665.; Cevdet Timar Ruznamçe (C. TZ). 168/8375.

Cumhurbaşkanlığı Arşiv Daire Başkanlığı Osmanlı Arşivi (BOA). Erzurum Ahkam Defterleri (A.DVNS.AHK. ER.). nr. 5. 
Cumhurbaşkanlığı Arşiv Daire Başkanlığı Osmanlı Arşivi (BOA). Hatt-ı Hümayun (HAT). 12/448-M.; 132/5047.; 186/8743.; 200/10231.; 63/ 2753-G.; 12/448-L.; $187 / 8827$.

Cumhurbaşkanlığı Arşiv Daire Başkanlığı Osmanlı Arşivi (BOA). İbnü’l Emin Tevcihat (IE. TCT). 23/2444.; 8/968.

Cumhurbaşkanlığı Arşiv Daire Başkanlığı Osmanlı Arşivi (BOA). Ali Emiri Sultan Ahmed III (AE. SAMD III). 85/8570.; 196/18941.

Cumhurbaşkanlığı Arşiv Daire Başkanlığı Osmanlı Arşivi (BOA). Tahvil Defteri. nr. 16.

Cumhurbaşkanlığı Arşiv Daire Başkanlığı Osmanlı Arşivi (BOA). Maliyeden Müdevver Defterleri (MAD. d), nr. 17679.

Cumhurbaşkanlığı Arşiv Daire Başkanlığı Osmanlı Arşivi (BOA). Ruznamçe Defterleri (DFE. RZ. d.) nr. 167, 220-A.

Cumhurbaşkanlığı Arşiv Daire Başkanlığı Osmanlı Arşivi (BOA). Tapu Tahrir Defteri (TT.d). nr. 898.

Tapu Kadastro Genel Müdürlüğü, Kuyûd-1 Kadîme Arşivi (TKGM. KKA. TT). Bayezid Sancă̆l ve Tevâbiha Mufassal Tahrir Defteri. nr. 199.

Ahmed Cevdet Paşa. Tarih-i Cevdet. III Cilt. İstanbul: Üçdal Neşriyat, 1966.

Akgündüz, Ahmet. Osmanl Kanunnameleri Hukuki Tahlilleri Merkezi ve Umumi Kanunnameleri 4. Kitap Kanuni Devri Kanunnameleri. İstanbul: Fey Vakfı Yayınları, 1992.

Ayn Ali Efendi. Kavânin-i Al-i Osman Der-Hülâsa-i Mezâmin-i Defter-i Divân. T.B.M.M Kütüphanesi Yazma Eserler, Nr.. KZ-334.

Mehmed Süreyya. Sicil-i Osmanî. Haz. Nuri Akbayar. 3 Cilt, İstanbul: Tarih Vakfı Yurt Yayınları, 1996.

Kâtip Çelebi. Kitab-ı Cihannüma li- Kâtip Çelebi. I Cilt. Tıpkıbasım, Ankara: Türk Tarih Kurumu Yayınları, 2009.

Şeref Han Bitlisi. Şerefnâme. Çev. Abdullah Yegin. I Cilt. İstanbul: Nûbihar Yayınları, 2013.

\section{B- Araștırma Eserler}

Başar, Fehamettin. Osmanlı Eyalet Tevcihatı (1717-1730). Ankara: Türk Tarih Kurumu, 1997.

Bingöl, Yüksel. “İshak Paşa Sarayı'nın Tarihlendirilmesi”. I. Uluslararası A ̆grı Dă̆ ve Nuh'un Gemisi Sempozyumu Bildirileri (Doğubayazıt, 7-11 Eylül 2005) Ed. Oktay Belli 1382-390. İstanbul: Doğubayazıt Kaymakamlığı, Çekül Vakfı ve diğ, 2004.

Çakır, Baki, "Kese", Türkiye Diyanet Vakfi İslam Ansiklopedisi, c. EK-2: 42-43. İstanbul: TDV Yayınları, 2016.

Çiftçi, Erdal. "Migration, Memory and Mythification: Relocation of Suleymani Tribes of the Northern Ottoman-İranian Frontier”. Middle Eastern Studies. 54/ 2. (2018): 270288.

Emecen, Feridun M. - Şahin, İlhan. "Osmanlı Taşra Teşkilatının Kaynaklarından 957958 (1550-1551) Tarihli Sancak Tevcih Defteri. Belleten. XIX/23, (1998): 53-98. 
Eyice, Semavi. "İshak Paşa Sarayı”, Türkiye Diyanet Vakfi İslam Ansiklopedisi, c. 22: 542-544. İstanbul: TDV Yayınları, 2000.

Gündoğdu, Hamza. Doğubayazıt İshak Paşa Sarayı. Ankara: T.C Kültür Bakanlığı Yayınları, 1991.

İnbaşı, Mehmet. "Çı1dır Beylerbeyleri: I. İshak Paşa ver II. İshak Paşa". Güneşin Doğduğu Yer: Doğubayazıt Sempozyumu Bildirileri (Doğubayazıt, 13-14 Eylül 2003) Ed. Oktay Belli 176-191. İstanbul: Doğubayazıt Kaymakamlığı, Çekül Vakfı ve diğ, 2004.

Karataş, Yakup. Bayezid Sancağl ve İdarecileri (1700-1914). İstanbul: Kitapevi, 2014.

Kaya, Hakan. Osmanlı-Iran Sinırında Bir Serhad Sancă̆ı: Bayezid (1578-1648). Doktora Tezi, Hacettepe Üniversitesi, 2018.

Kaya, Hakan. "Ahmed-i Hâni'nin Divanında Tarihi Bir Şahsiyet: Muhammed Pürbelali”, 2. Uluslararası Ahmed-i Hani Sempozyumu İslam Düşüncesinde İnsan (Doğubayazıt 28-30 Eylül 2018), Ed. Abdulcebbar Kavak. 182-193. Ağrı: Ağrı İbrahim Çeçen Üniversitesi Yayınları, 2018.

Kılıç, Orhan. “Ocaklık Sancakların Osmanlı Hukukunda ve İdari Tatbikattaki Yeri”. Firat Üniversitesi Sosyal Bilimler Dergisi.11/1. Elazı̆g. (2001): 257-274.

Kunt, Metin. Sancaktan Eyalete 1550-1650 Arasında Osmanlı Ümerası ve İ İdaresi, İstanbul: Boğaziçi Üniversitesi Yayınları, 1978.

Öz, Mehmet. "Osmanlı İdaresinde Kürtler ve Özerklik: Efsane mi Gerçek mi? (XVIXVIII. Yüzyıllar)”. Türkiye Günlüğü Dergisi, 99 (Güz 2009): 154-169.

Yaycioğlu, Ali. Partners of the Empire: The Crisis of the Ottoman Order in the Age of Revolutions. California: Stanford Üniversity Press, 2016. 